\title{
Suramin inhibits cell proliferation in ovarian and cervical cancer by downregulating heparanase expression
}

\author{
HuaPing Li ${ }^{1}$, HuaLi Li ${ }^{2}$, HongJie Qu ${ }^{3}$, MingZhu Zhao ${ }^{1}$, Bo Yuan ${ }^{3}$, MingHua Cao ${ }^{1}$ and JinQuan Cui ${ }^{3 *}$
}

\begin{abstract}
Background: Aberrant expression of heparanase ( $\mathrm{Hpa}$ ) is associated with apoor prognosis in ovarian and cervical cancer patients. Inhibitors of Hpa can prevent the growth and metastasis of malignant tumor cells, and suramin may be such a compound that has strong anti-proliferative effects on several kinds of cancer cells. We have therefore tested whether the growth inhibiting effect of suramin on ovarian and cervical cancer cells is due to downregulation of Hpa expression.

Results: Suramin at 300-600 $\mathrm{\mu g} / \mathrm{ml}$ significantly inhibited HO-8910 PM and HeLa cell growth at $24 \mathrm{~h}$, in both a time-dependent and dose-dependent manner, with an $\mathrm{IC}_{50}$ of $320 \mu \mathrm{g} / \mathrm{ml}$ and $475 \mu \mathrm{g} / \mathrm{ml}$, respectively. Suramin at $300 \mu \mathrm{g} / \mathrm{ml}$ significantly decreased the expression of Hpa mRNA $(P<0.005)$ and protein $(P<0.005)$ in both HO-8910 PM and HeLa cells at $48 \mathrm{~h}$.

Conclusions: The inhibitory effect of suramin on Hpa enzyme may be due to downregulating of its expression in cancer cells. These findings confirm the importance of $\mathrm{Hpa}$ in tumor growth and the potential clinical application of Hpa inhibitors in the treatment of ovarian and cervical cancer.
\end{abstract}

Keywords: Suramin, Inhibition, Heparanase, Ovarian cancer, Cervical cancer

\section{Background}

Ovarian cancer is the fifth most common cause of cancer death among females and ranks as the first cause of death in gynecologic malignancies. Due to no effective early detection methods, $\sim 70 \%$ ovarian cancers are often diagnosed at advanced stage. With the introduction of new treatment modalities, clinical results have been significantly improved, but the ovarian cancer 5-year survival rate is only $44 \%$ [1]. Uterine cervical cancer is another major healthcare concern worldwide, especially in the less developed countries. Despite advances in screening, vaccination and treatment of early stage disease, advanced stage tumour, its recurrence and distant metastasis are the main causes of treatment failure and death. Although systemic chemotherapy or radiochemotherapy remains the standard treatment for those patients, their responses to cytotoxic drugs are not satisfactory, and

\footnotetext{
* Correspondence: cui_jq@126.com

${ }^{3}$ Department of Gynaecology and Obstetrics, The Second Affiliated Hospital of Zhengzhou University, Longitude eighth Road, Zhengzhou, China Full list of author information is available at the end of the article
}

no truly effective second and third line therapeutic regimens are in place. Therefore, new strategies are needed to improve survival and enhance responsiveness to cytotoxic drugs. Molecular target treatment is more effective in most cancers, and is now widely used. Several clinical trials of molecular target treatment have demonstrated their effectiveness in ovarian and cervical cancer [2-7]. But some pitfalls should not be ignored, especially relating to the problem of resistance that is a major challenge facing clinicians. There is the need to develop a second-line treatment strategy for the increasing number of patients who become resistance to the molecular agents.

$\mathrm{Hpa}$ is an endo- $\beta$-glucuronidase that cleaves heparan sulfate proteoglycans within the extracellular matrix, basement membrane or on the cellular surface, directly or indirectly enhancing cell invasion, migration, and intravasation and extravasation, by releasing various growth factors from heparin-binding [8-10]. Overexpression of $\mathrm{Hpa}$ in tumor cells markedly enhances their growth, angiogenesis, and metastasis [11]. Ovarian and cervical carcinomas express higher levels of Hpa mRNA 
and protein, which is associated with tumor stage at high grade and advanced stage [12-14]. Davidson et al. [15] reported that the expression of Hpa in ovarian cancer is $53 \%$ and $90 \%$ at the cell membrane and cytoplasm, respectively. Membrane expression in $>5 \%$ of tumor cells correlates with a shorter overall survival. Immunohistochemical positivity for heparanase was $63.3 \%$ (38/60) in cervical cancer patients [14]. Hpa expression is also an independent predictor of poor overall survival, suggesting it is involved in tumor metastasis of female genital tract malignancies [16]. Interestingly, elevated serum Hpa levels correlate with malignant invasion and progression in ovarian cancer [17], which may facilitate disease diagnosis and treatment surveillances. Hpa inhibitor has strong anti-proliferation activity in vitro against two human ovarian cell lines, OVSAHO and SKOV-3 [18], and may be one of the potential tumor molecular target therapeutics. A potent Hpa inhibitor, PI-88 (a Phase I/II trials product), is effective in several types of tumor $[19,20]$. Hpa could lead to a new therapeutic strategy for patients with advanced female genital tract malignancies.

Suramin (8,8' -carbonyl-bis [imino-3,1-phenylenecarbonylimino (4-methyl-3,1- phenylene) carbonylimino] bis1,3,5-naphthalene-trisulfonic acid) was originally used to treat African parasitic infections, such as Rhodesian and Gambian trypanosomiasis. Due to its anti-proliferative activity against several human tumor cell lines in dose- and time-dependent fashion [21], suramin alone or combined with cytotoxic drugs has been studies in many clinical trials that include ovarian cancer [22,23]. The antiproliferative mechanism of suramin is still not fully understood, but its activity may be due to it inhibiting the binding of growth factors to their receptors and dissociating receptor-bound growth factors, consequently resulting in loss of signal transduction [24]. Suramin is also considered a potent inhibitor of several nuclear enzymes in vitro, including DNA primase, DNA polymerase $\alpha$, RNA polymerase, DNA topoisomerase II, and reverse transcriptase, which may be important to its cytotoxic activity. Suramin and suramin analogues has also been shown to inhibit Hpa in many human cancer cell line by independent groups [25-28]. Suramin inhibits local tumor invasion and distant metastasis by both a direct and an indirect effect on cell adhesion and migration. New suramin analogues have now been developed to try to improve this antitumor activity and overcome its side-effects [29].

Although suramin significantly inhibits the growth of ovarian cancer and is used in clinical trials, its antiproliferative effect is not properly understood. Indeed, this lack of knowledge of the drug's primary mechanism of action has prevented use of suramin in female genital tract malignancies. Accordingly, our study has focused on the in vitro cytotoxic activity of suramin against human ovarian and cervical cancer cells. We found that suramin significantly downregulates Hpa expression in its inhibitory effect on the growth of cancer cells.

\section{Results}

Changes of cell morphology in HO-8910 PM cells and HeLa cells after suramin treatment

Changes of cell morphology in HO-8910 PM cells and HeLa cells were explored as part of its dose-response and time-response effects. Clear changes were observed 48 and $96 \mathrm{~h}$ post-treatment. Cell density and nonadhesiveness of cells began to decrease and dispersion into single cells increased after $50 \mu \mathrm{g} / \mathrm{ml}$ suramin treatment within $48 \mathrm{~h}$. Membrane blebbing and increased cytoplasmic volume occurred, and viable cells markedly decreased, with dead cells floating and clumping up, in $300 \mu \mathrm{g} / \mathrm{ml}$ suramin within $96 \mathrm{~h}$, suggesting that HO8910 PM cells and HeLa cells were undergoing apoptosis (Figure 1b).

\section{Growth changes in HO-8910P and Hela cells after suramin treatment}

The growth of the HO-8910 PM and Hela cells using the MTT assay showed that different doses of suramin significantly inhibited growth rate from 24 to 96 (Figure 2a). Inhibition with $600 \mu \mathrm{g} / \mathrm{ml}$ suramin at $96 \mathrm{~h}$ reached $70.9 \%$ in HO-8910 PM cells and 59.5\% in Hela cells. Except for the $50 \mu \mathrm{g} / \mathrm{ml}$ group vs $100 \mu \mathrm{g} / \mathrm{ml}$ group, inhibition of the other groups of HO-8910 PM cells showed significant differences $\quad$ (Ftime $=38.128$, Ptime $=0.0001$,Fdose $=44.984$, Pdose $=0.0001)$. For HeLa cells, except for $50 \mu \mathrm{g} / \mathrm{ml}$ group vs $100 \mu \mathrm{g} / \mathrm{ml}$, and vs $200 \mu \mathrm{g} / \mathrm{ml}$ group, inhibition of the other groups was significantly different (Ftime = 20.548, Ptime $=0.0001$, Fdose $=32.324$, Pdose $=0.0001$ ) The IC50 values of HO-8910 PM and HeLa were $319 \mu \mathrm{g} / \mathrm{ml}, 476 \mu \mathrm{g} / \mathrm{ml}$, respectively (Figure $2 \mathrm{~b}$ ). Plasma concentration of $\geq 350 \mu \mathrm{g} / \mathrm{ml}$ suramin led to a doselimiting neurotoxicity [30]. At $96 \mathrm{~h}$, treatment with 200 and $300 \mu \mathrm{g} / \mathrm{ml}$ suramin inhibited $35.1-43.7 \%$ of HO-8910 PM cell growth and 22.4-31.7\% of Hela cell growth, confirming the toxic nature of suramin. Flow cytometry was used to detect apoptosis rate in HeLa cells (Figure 2c).The level in cells given $300 \mu \mathrm{g} / \mathrm{ml}$ suramin for $48 \mathrm{~h}$ was significantly lower than in untreated cells $(300 \mu \mathrm{g} / \mathrm{ml}$ group $12.91 \pm 1.17 \% \mathrm{vs}$ UCG $5.01 \pm 1.07 \%, \mathrm{p}=0.001)$.

\section{Suramin inhibits HO-8910 PM and Hela cell proliferation} Proliferation of HO-8910 PM and HeLa cells treated with suramin showed time-dependency and dose-dependency. With increasing of dose and time, proliferation gradually decreased until $96 \mathrm{~h}$. OD values of different groups $(24,48,72$ and $96 \mathrm{~h})$ and 7 different doses $(50,100,200,300,400,500,600 \mu \mathrm{g} / \mathrm{ml})$ were significantly 


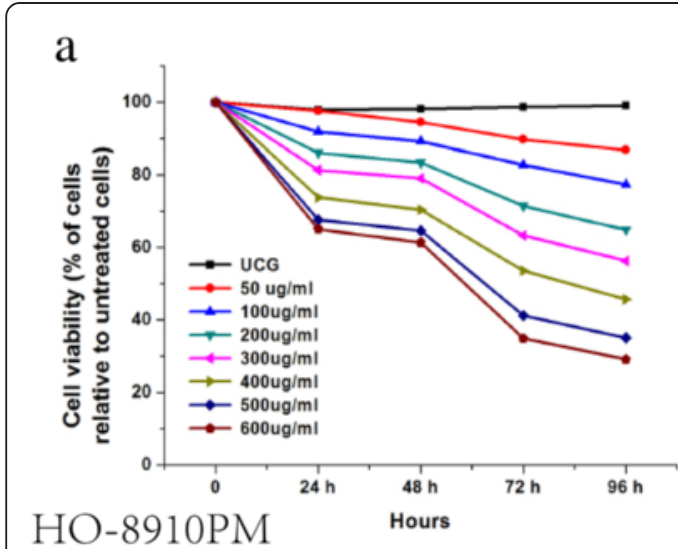

\section{b cellular morphological}

HO-8910PM
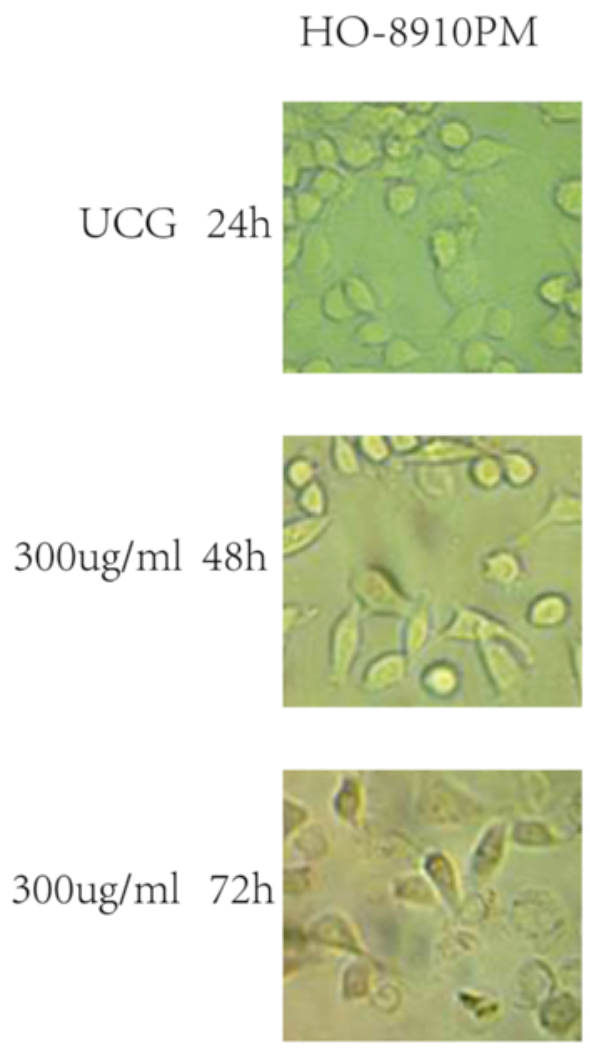

Hela
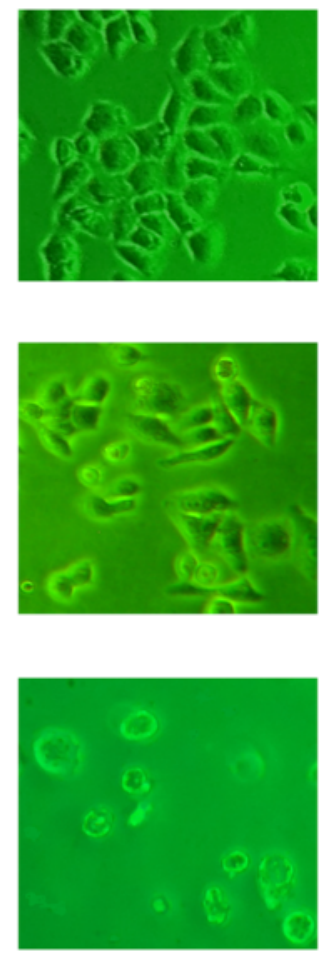

\section{UCG $=$ Untreatred control group}

Figure 1 Suramin decreases viability in HO-8910 PM ovarian cancer cells and Hela cervical cancer cells. HO-8910 PM and Hela cells were treated with Hpa inhibitor Suramin $(50,100,200,300,400,500$ and $600 \mu \mathrm{g} / \mathrm{ml})$. The cells $\left(1 \times 10^{4}\right)$ were incubated at these concentrations for 24,48 , 72 and $96 \mathrm{~h}$ at $37^{\circ} \mathrm{C}$ in a humid air atmosphere containing 5\% CO $\mathrm{CO}_{2}$ in RPMI-1640 culture medium. Subsequently, 3-(4,5-dimethylthiazol-2-yl)2,5-diphenyltetrazolium bromide (MTT) was added and the cells were incubated for 4 h; viability was assessed by measuring the OD at $490 \mathrm{~nm}$, the value of the untreated control group (UCG) being taken as 100\%. The assay showed that the HO-8910 PM and Hela cell vialibility decreased in a dose-dependent and time-dependent manner $(\mathbf{a}, \mathbf{c})$. After $48 \mathrm{~h}$ treatment with $300 \mathrm{\mu g} / \mathrm{ml}$ suramin, morphological changes became increasingly significant, and viable cells decreased markedly with dead cells floating and clumping in the culture media at $72 \mathrm{~h}$ (examined at 4-40X magnification using a Leica DMLB microscope) (b). Statistical analysis, the one-way ANOVA. ${ }^{*} \mathrm{P}<0.05$ 24, 48, 72 and $96 \mathrm{~h}$ vs the UCG; 24 vs $72 \mathrm{~h}$, or 96 h; 48 vs 72 h, or 96 h; 72 vs 96 h; $\bullet P<0.05$ 100, 200, 300, 400, 500,or $600 \mu \mathrm{g} / \mathrm{ml}$ vs the UCG; 100 vs 300, 400, 500,or 600 $\mu \mathrm{g} / \mathrm{ml}, 200$,vs 300, 400, 500 or $600 \mu \mathrm{g} / \mathrm{ml}, 300$ vs 400,500 , or $600 \mu \mathrm{g} / \mathrm{ml}, 400$ vs $500,600 \mu \mathrm{g} / \mathrm{ml}, 500$ vs $600 \mu \mathrm{g} / \mathrm{ml}$.

lower than the untreated controls (UCG) $\left(\mathrm{F}_{\text {time }}=480\right.$, $\mathrm{P}_{\text {time }}=0.0001, \mathrm{~F}_{\text {dose }}=1655, \mathrm{P}_{\text {dose }}=0.0001$ for HO-8910 PM; $F_{\text {time }}=126, \mathrm{P}=0.0001 ; \mathrm{F}_{\text {dose }}=768, \mathrm{P}_{\text {dose }}=0.0001$ for HeLa). For statistical analysis of inter-group OD values in both HO-8910 PM and HeLa cells, all p values were equal to 0.0001 ( 0.000 is not a value) either in 4 different time groups or in 7 different dose groups, except for the $24 \mathrm{~h}$ vs 48 h groups (Figures 3, 4, 5 and 6).

\section{Suramin downregulates the expression of Hpa protein and mRNA in HO-8910 PM and Hela cells}

Suramin downregulation of the expression of Hpa protein in HO-8910 PM and Hela cells was investigated by immunocytochemistry. From the MTT results, we selected
$300 \mu \mathrm{g} / \mathrm{ml}$ suramin and $48 \mathrm{~h}$ treatment as appropriate (Figure 7b). Compact brown or yellow immune particles of Hpa protein and blue hybridized granules of Hpa mRNA were present in the cytoplasm in the experimental control group, distributed diffusely in all fields (Figure 7c). Staining in the suramin group decreased significantly in intensity as well as integration $\left(X^{2}=25.958, P=0.0001, X^{2}=27.091, P=0.0001\right)$. Realtime quantitative-PCR was used to determine Hpa mRNA expression in HeLa cells (Figure 3a). The level in cells given $300 \mu \mathrm{g} / \mathrm{ml}$ suramin for $48 \mathrm{~h}$ was significantly lower than in untreated cells $(300 \mu \mathrm{g} / \mathrm{ml}$ group $0.92 \pm 0.87$ vs UCG $3.62 \pm 2.80$, p <0.05), with downregulation being 3.93 fold lower. 


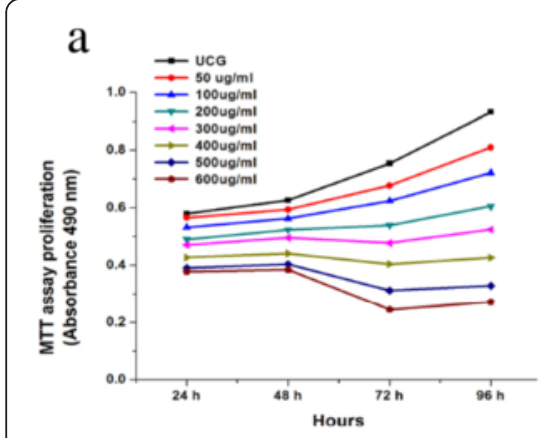

HO-8910PM

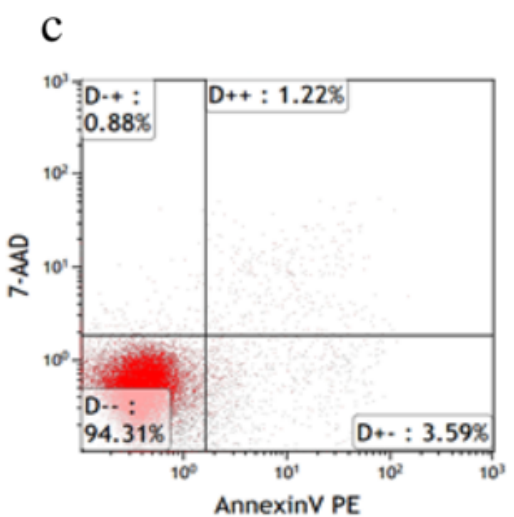

Hela UCG

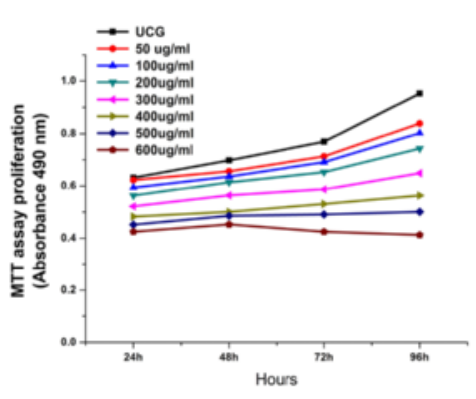

Hela

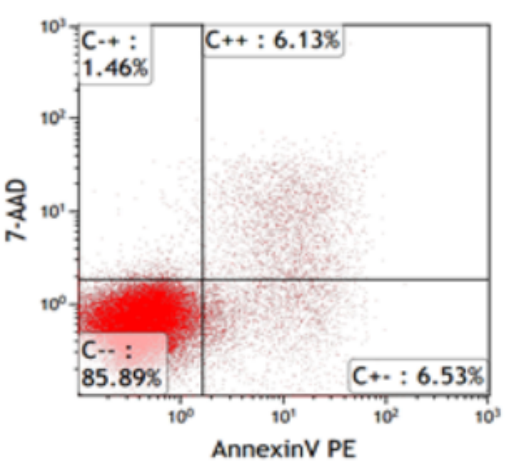

Hela 300ug/ml 48h b

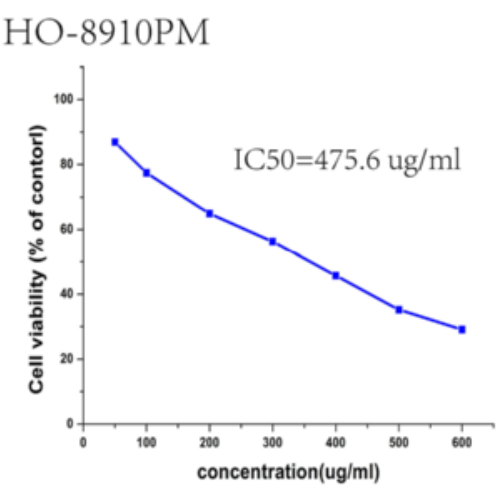

Hela

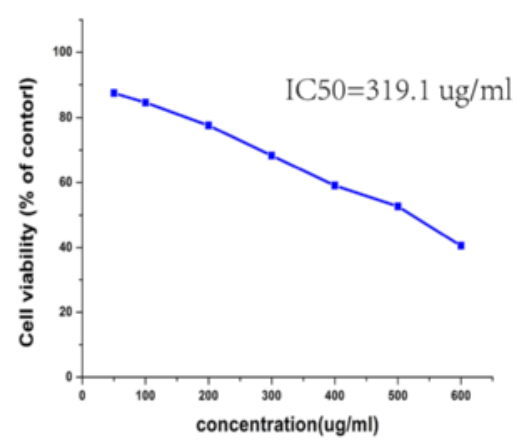

\section{$\mathrm{UCG}=$ Untreatred control group}

Figure 2 Suramin decreases the proliferation of HO-8910 PM and Hela cells. MTT assay showed that HO-8910 PM and Hela proliferation was inhibited in a dose-dependent and time-dependent manner after suramin treatment (a). IC50 value of HO-8910 PM was 319 Hg/mL, IC50 value of Hela was $319.1 \mathrm{\mu g} / \mathrm{mL}$ (b). Flow cytometry was used to detect apoptosis rate in HeLa cells (Figure 2c).The level in cells given 300 $\mu \mathrm{g} / \mathrm{ml}$ suramin for $48 \mathrm{~h}$ was significantly lower than in untreated cells $(300 \mu \mathrm{g} / \mathrm{ml}$ group12.91 $\pm 1.17 \% \mathrm{vs}$ UCG 5.01 $\pm 1.07 \%, \mathrm{p}=0.001)$ (c).

\section{Discussion}

Suramin treatment significantly decreases cell growth in a dose- and time-dependent manner in HO-8910 PM and HeLa cells, consistent with previous reports [21,31,32]. Although the $\mathrm{IC}_{50}$ of suramin against in HO-8910 PM cell was 10 times higher compared with other studies, it was lower than the cytotoxic concentrations $>275 \mu \mathrm{M}$ in human blood serum [22]. Thus suramin not only downregulates Hpa protein and mRNA expression, but inhibits the growth of cancer cells.

Suramin is a multiple sulfonic acid naphthoquinone salt that has anti-proliferative activity against many cancers, with a wide range of $\mathrm{IC}_{50}$ values. Suramin at $275 \mu \mathrm{M}$ sustained over several weeks has been associated with severe multitoxicity, including renal toxicity, adrenal insufficiency, immune- and anticoagulant-mediated blood dyscrasias, and dermatological toxicity [33-35]. We found the $\mathrm{IC}_{50}$ of suramin to be $319 \mu \mathrm{g} / \mathrm{ml}$, and at 200 and $100 \mu \mathrm{g} / \mathrm{ml}$ it could inhibit cell growth by 35.1 to $43.7 \%$, while at $210 \mu \mathrm{g} / \mathrm{ml}$ it effectively decreased CA125 serum levels of the patients with ovarian cancer.
Non-cytotoxic doses of suramin ranging between 10 and $50 \mu \mathrm{M}$ enhances the antitumor effects of several chemotherapeutic agents in a number of tumor cell lines [36] and several animal models [37]. Despite the U.S. Food and Drug Administration disapproving the use of suramin at therapeutic concentrations, 2 clinical trials at non-cytotoxic suramin levels in combination with chemotherapeutic agents have been conducted to treat metastatic breast cancer [38] and advanced nonsmall cell lung cancer [22], with discernible antitumor activity being noted in the latter. Thus, low or noncytotoxic doses of suramin might be used as effective chemosensitizers to cytotoxic drugs, ie as an adjuvant, for ovarian cancer in the future.

Inhibiting the activity of key enzymes is an important anti-proliferative mechanism of suramin at therapeutic. A growing body of evidence has shown that suramin is the inhibitor of such enzymes as histone methyltransferases [39], histone deacetylases [40], ATPase [41], DNA topoisomerase [42] and Hpa [28]. However, Hpa has been the target molecule here because it is important in 


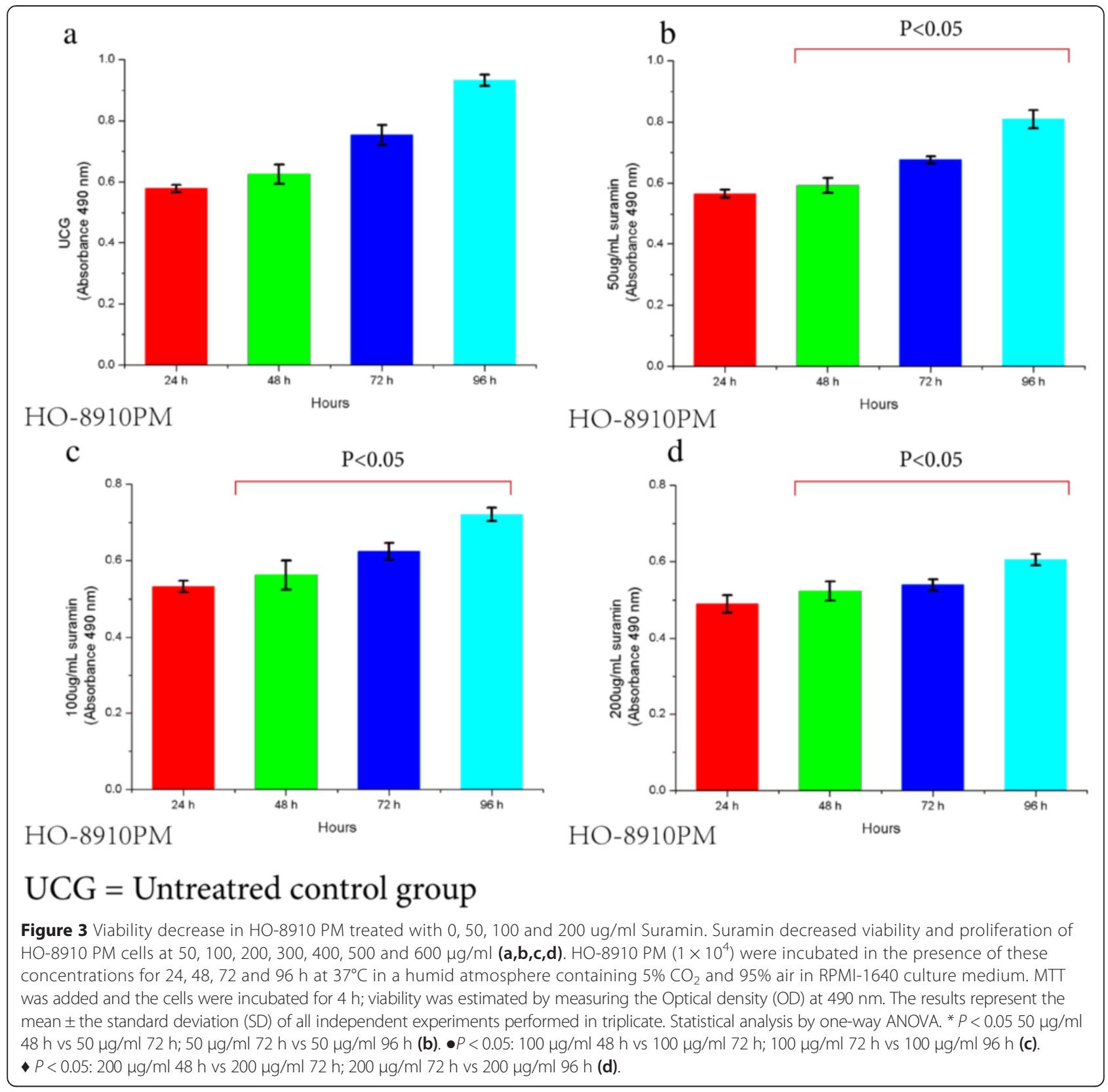

tumor cell metastasis through the degradation of heparan sulfate proteoglycans in the extracellular matrix. The human Hpa gene is located on chromosome 4q21.3 with a full-length cDNA of $1758 \mathrm{bp}$ and its active protein product is $50 \mathrm{kD}$. Because of the inherent role of $\mathrm{Hpa}$, inhibition of its activity makes it a potential target in anti-cancer therapy. Numerous Hpa inhibitors are being developed and tested for growth inhibition of tumors. PI88, one of the inhibitors, has been already used in clinical trials.

New suramin analogues have been synthesized possessing highly anti-proliferative effects on tumor cells in vitro and angiostatic effects compared with suramin itself. Marchetti et al. [28] reported that the IC50 of suramin on Hpa activity in melanoma $70 \mathrm{~W}$ cells was $42 \mu \mathrm{M}$, much higher than the IC50 values of suramin analogues (NF 127, NF 145 and NF 171) in a range of 20-30 $\mu \mathrm{M}$. They also found that $\mathrm{Hpa}$ expressed in $70 \mathrm{~W}$ cells was effectively inhibited by suramin analogues in a dose-dependent manner. Complete inhibition was obtained at $100 \mu \mathrm{M}$ and higher. In our study, HO-8910 PM with its high expression of Hpa protein and mRNA comes from a peritoneal metastasis of epithelial ovarian cancer. Treatment with $300 \mu \mathrm{g} / \mathrm{ml}$ suramin significantly decreased Hpa mRNA and protein expression at $48 \mathrm{~h}$, which not only support previous 


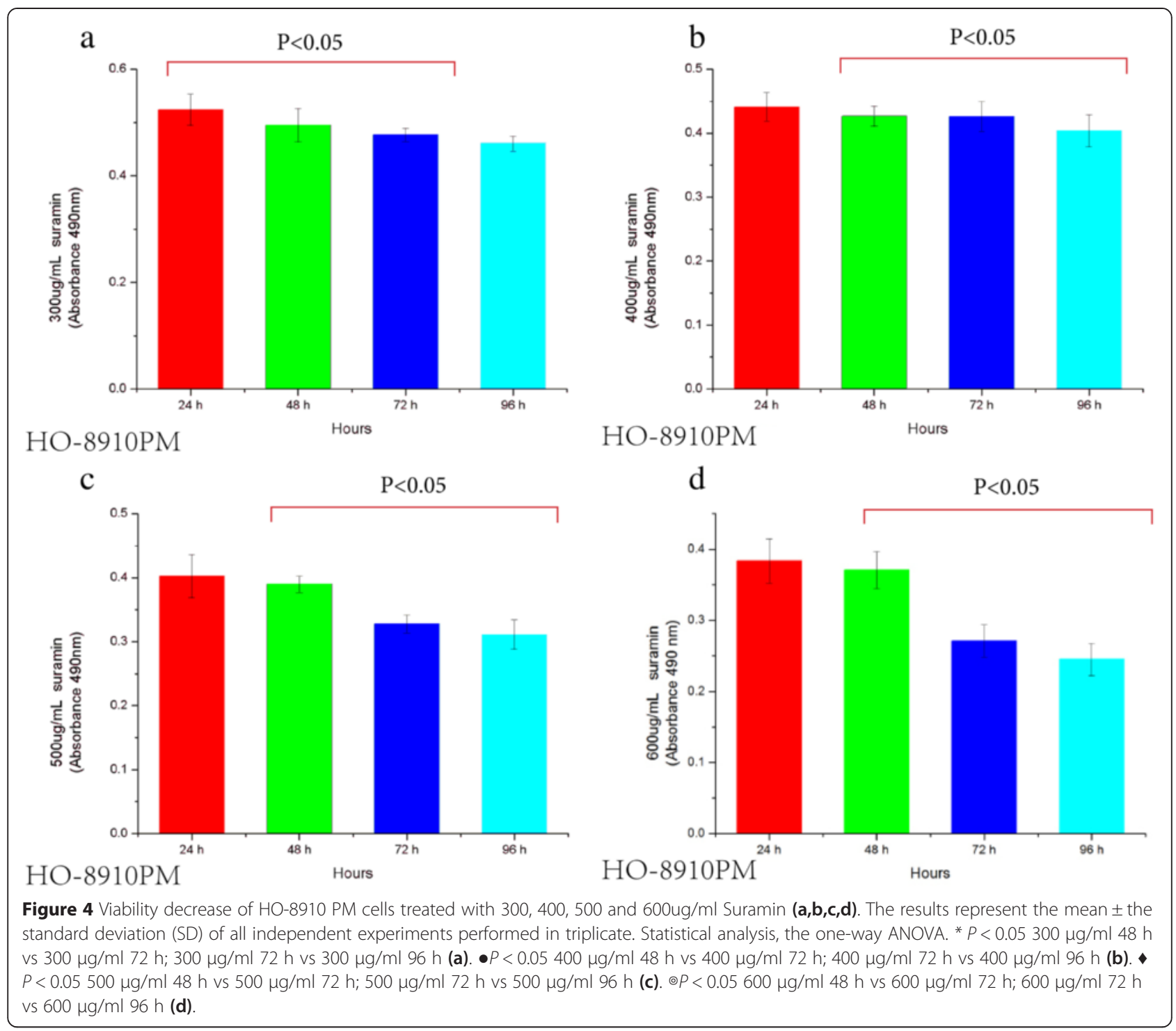

studies, but extend our understanding of the antiprolierative mechanism of suramin on ovarian cancer.

Zeng et al. [14] found 63.3\% cervical cancers expressed $\mathrm{Hpa}$, and overexpression of heparanase inhibited apoptosis of cervical cancer cells. Ectopic heparanase overexpression can promote proliferation of cervical cancers in vitro and tumor growth in vivo. High risk human papillomavirus (HR-HPV) infection has been considered a primary cause of cervical cancer because it is present in the $99.7 \%$ of cervical cancers $[43,44]$, which leads to \#0.5 million cases per year. HPV 16 and 18 are the most common HR-HPV types worldwide and account for $\sim 70 \%$ of cervical squamous cell carcinomas and up to 85\% of the adenocarcinomas. HPV16 E6 and HPV 18 E7 are best known for their ability to target the 2 tumor suppressors, p53 and pRb [45]. The HPV16 oncogene E6 is capable of inducing overexpression of heparanase in head and neck squamous cell carcinoma in vitro, which can be suppressed by radiation in a dose-dependent manner. The heparanase gene is regulated through wildtype p53 binding to the heparanase promoter [46]. E6mediated degradation served as the major mechanism inactivating p53 [47] that might lead to induction of heparanase expression and promote cervical carcinogenesis. Therefore, this study provides important experimental evidence of Hpa-targeted therapy for cervical cancer. Our investigations will now focus on HPV E6 inhibition by suramin.

In conclusion, suramin inhibits strongly the growth of human ovarian and cervical cancer cells, and at same time significantly downregulates Hpa expression. We suggest that the antitumor activity of suramin may partly relate to inhibition of Hpa expression in cancer cells. Therefore, combination of low dose suramin and chemotherapeutic 


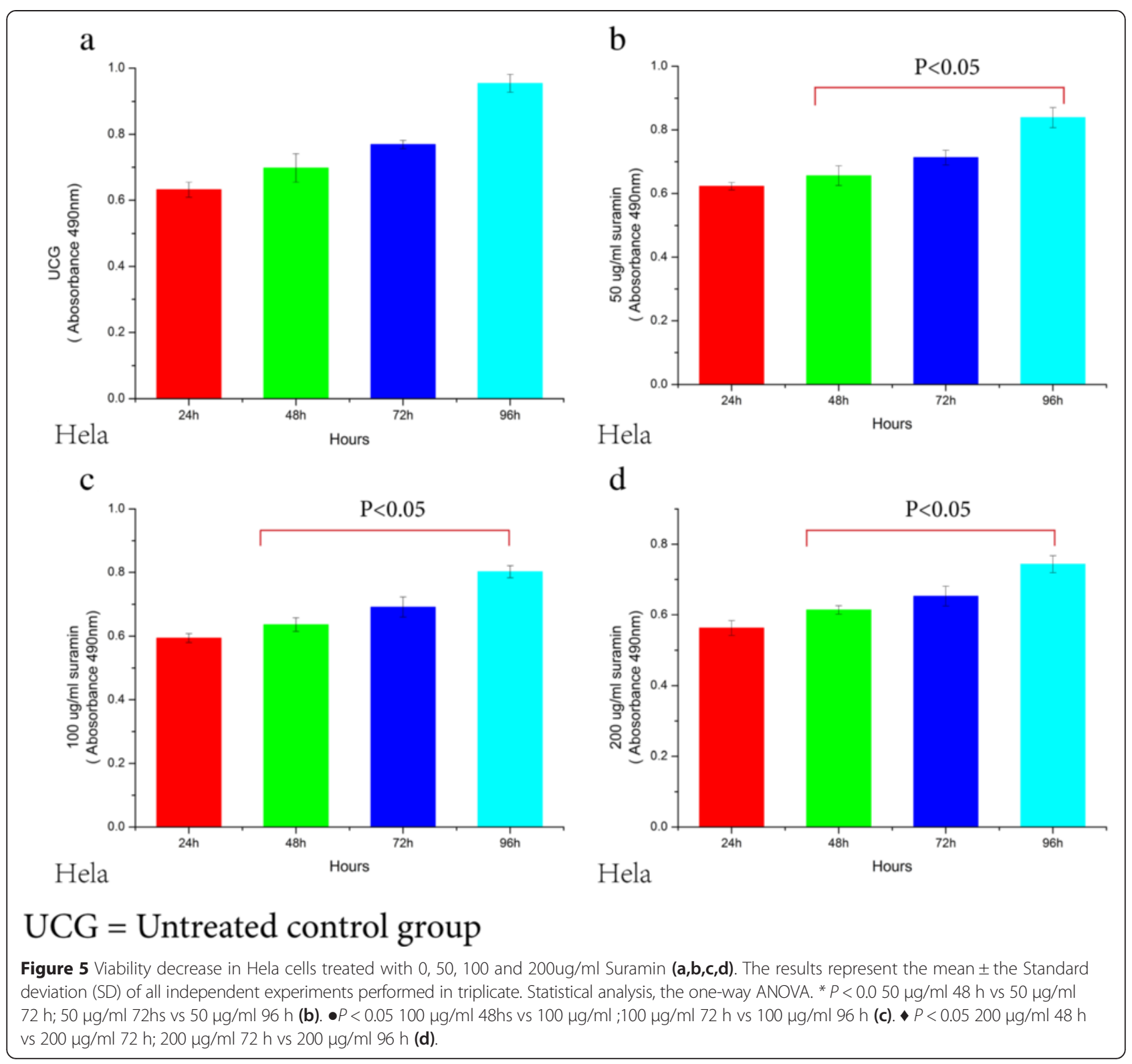

agents for the advanced female genital tract malignancies might be a suitable means of treatment in the future.

\section{Conclusions}

Suramin as a Hpa inhibitor can inhibit the growth of HO-8910 PM and HeLa cells and at same time significantly downregulates Hpa expression.

\section{Methods}

\section{Cell lines and reagents}

Human ovarian cancer cell line, HO-8910 PM, classified as a highly malignant peritoneal metastatic carcinoma with a highly metastatic potential, was obtained from Shanghai institutes for biological sciences (Shanghai, China). Human Cervical cancer line Hela was also obtained from the same source. Suramin as its sodium salt was purchased from EMD Millipore (Billerica, MA, USA). Hpa antibody was purchased from Santa Cruz Biotechnology (Santa Cruz, CA, USA). SP immunohistochemical and DAB kits were purchased from the Beijing Sequoia (Beijing, China). The biotin-labeled Hpa probe was obtained from Beijing Aoke biotechnology company (Beijing, China), and the mRNA sequence was $5^{\prime} \mathrm{TCA}$ ATG GTG ACG GAC AGG AAC GAG G 3'. In situ hybridization reagent box was the production of Boster (Wuhan, China).

\section{Culture}

HO-8910 PM and Hela cells were cultured in RPMI1640 (Logan, UT, USA) supplemented with 10\% fetal 


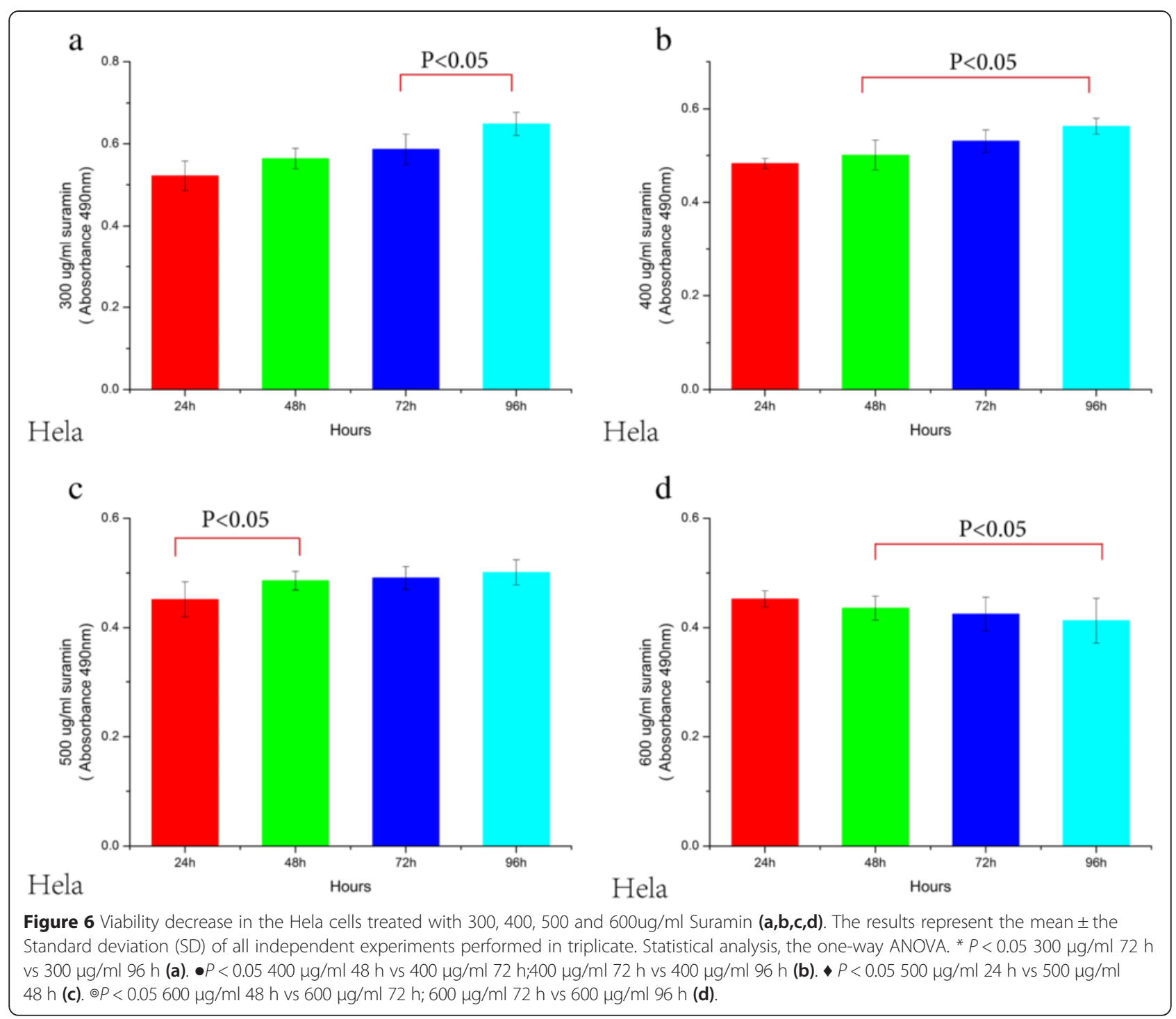

bovine serum and incubated at $37^{\circ} \mathrm{C}$ in a humidified incubator with air plus $5 \% \mathrm{CO}_{2}$. The cells at $80 \%$ confluence in logarithmic growth phase were used for experiments. Viability was $>95 \%$, as estimated by trypan blue staining.

\section{Preparation of adherent cell slides}

HO-8910 PM and Hela cells in logarithmic growth phase were detached by digesting with $0.25 \%$ trypsin plus $0.02 \%$ EDTA. One $\times 10^{4}$ cells in $1 \mathrm{ml}$ RPMI-1640 medium supplemented with $10 \%$ FBS were seeded on to coverslips pre-placed in welsl in a 24-well plate. After attachment of $70-80 \%$, the medium was poured off and the layer washed twice with ice-cold PBS. The coverlips were removed and transferred to new fresh 24-well plates. They were incubated in $4 \%$ paraformaldehyde at $4^{\circ} \mathrm{C}$ for $30 \mathrm{~min}$ and washed twice with PBS before being kept at $20^{\circ} \mathrm{C}$ for a week.

\section{MTT assay}

Cells were seeded in culture medium in a 96-well plate at $1 \times 10^{4}$ cells/well. After overnight incubation, cells were treated with different concentrations of suramin. MTT (3-(4,5-Dimethylthiazol-2-yl)-2,5-diphenyltetrazolium bromide) assay was used to measure tumor cell viability at from after 24 to $96 \mathrm{~h}$ of incubation. The cells were then stained with MTT (Amresco, Solon, $\mathrm{OH}$, USA) for $4 \mathrm{~h}$. The medium was discarded, and the cells were solubilized with $150 \mu \mathrm{l}$ DMSO for $15 \mathrm{~min}$, and the plate shaken gently for 10-15 min. The wells without suramin treatment were used as the untreated control groups, and sextuplicate wells were tested for each concentration. Each experiment was repeated 3 times. Photometric value A (OD value) at $490 \mathrm{~nm}$ was measured by a microplate reader. Growth inhibition rate (GI) was calculated according to the following formula: 


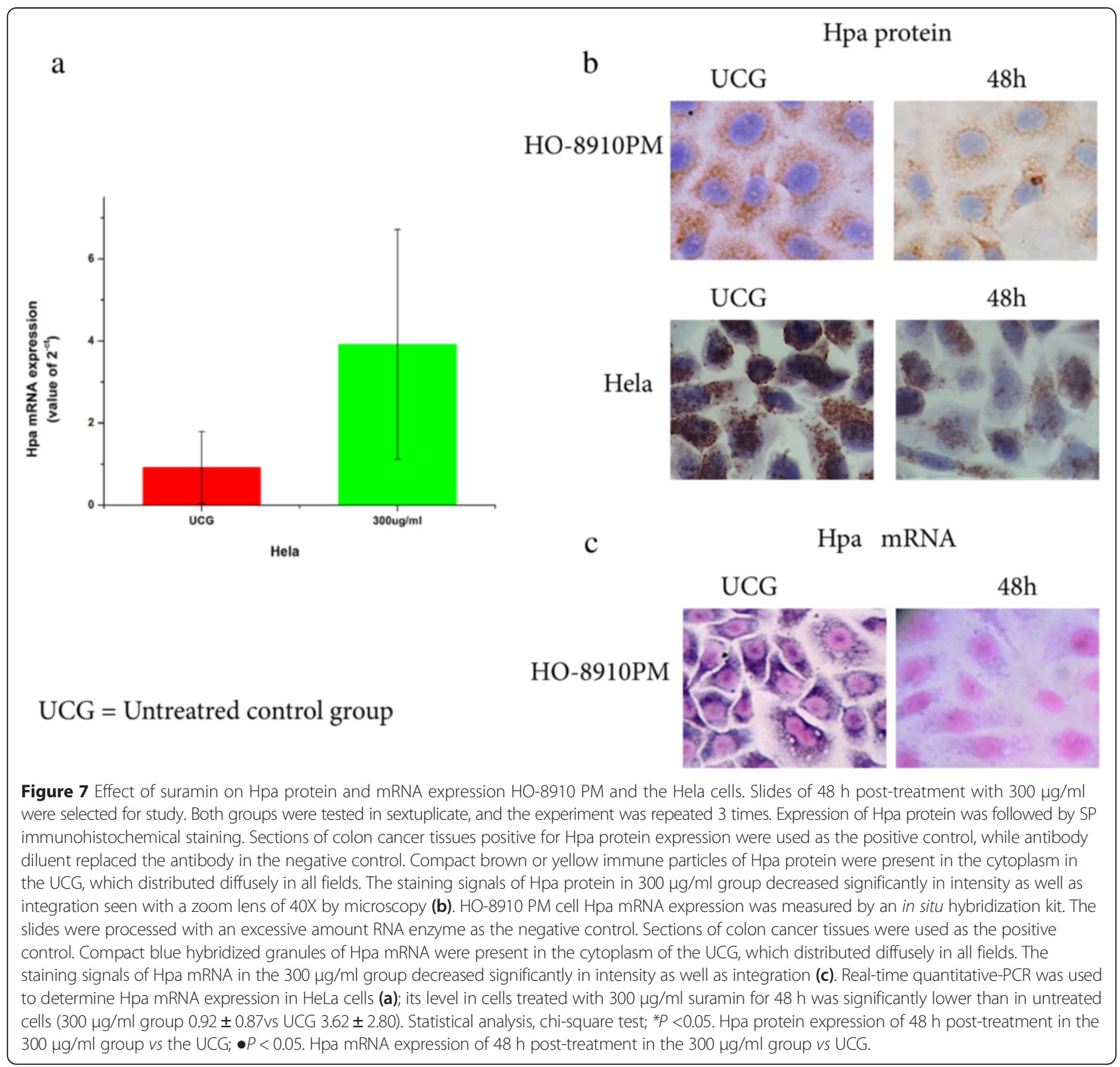

$\mathrm{GI} \%=[1-\mathrm{A} 490($ experimental group $) / \mathrm{A} 490($ untreated control group $)$ $\times 100]$.

\section{Immunocytochemistry}

Hpa expression was examined by the SP immunohistochemical method. Briefly, after treated with $3 \%$ hydrogen peroxide for $20 \mathrm{~min}$, cell slides were incubated overnight at $4^{\circ} \mathrm{C}$ with primary anti-Hpa antibody (1: 100). DAB (Diaminobenzidine) staining was given for $10 \mathrm{~min}$. Following hematoxylin counterstaining, the slides were sealed with neutral gum. Sections of colon cancer tissues positive for Hpa expression were used as control, while antibody diluent replaced the Hpa antibody as the negative control.
The slides of suramin treatment were defined as the experiment group, and slides without suramin were the untreated controls. Both groups were tested in sextuplicate, and the experiment was repeated 3 times.

\section{In situ hybridization}

The equipment and buffers were treated for the hybridization test with diethylpyrocarbonate (DEPC, Sigma-Aldrich, St Louis, MO, USA). After being washed with 50 and 30\% alcohol, sterile water and PBS at room temperature, the cells on the slides were permeated in $0.3 \%$ Triton X-100/PBS for $10 \mathrm{~min}$ and digested with 3\% pepsin diluted in fresh citric acid for $20 \mathrm{~min}$ at $37^{\circ} \mathrm{C}$. After being washed in PBS for 5 min, the slides were 
post-fixed with $4 \%$ paraformaldehyde for $10 \mathrm{~min}$ at room temperature. Each slide was dripped with $20 \mu \mathrm{l}$ hybridization solution and pre-hybridized in the wet box at $37^{\circ} \mathrm{C}$ for $3-4 \mathrm{~h}$. Hpa probe $(6-12 \mathrm{ng} / 20 \mu \mathrm{l})$ was added to each slide. The slides were covered with wax membrane and hybridized for $12 \sim 16 \mathrm{~h}$ at $42 \sim 43^{\circ} \mathrm{C}$, The slides were washed followed by washing four times in $0.2 \times \mathrm{SSC}$ at $42^{\circ} \mathrm{C}$ for $15 \mathrm{~min}$. They were then incubated in $1 \%$ acetylated $\mathrm{BSA}$ at $20^{\circ} \mathrm{C}$ for $10 \mathrm{~min}$ and in freshly diluted buffer SA-AP (Promega, Madison, WI) for $20 \mathrm{~min}$ at $37^{\circ} \mathrm{C}$. After washing with Tris- $\mathrm{HCl}$ buffer I 3 times and in Tris- $\mathrm{HCl}$ buffer II twice, the slides were protected from light and colored in freshly prepared BCIP/NBT (Promega) for 100-120 min. They were then stained with nuclear fast red for several min and sealed with neutral gum. The negative experimental control slides were processed with an excess of RNA enzyme. Sections of colon cancer tissues with positive expression of $\mathrm{Hpa}$ were used as positive experimental controls. Both groups were tested in sextuplicate, and the experiment was repeated 3 times.

\section{Interpretation of immunocytochemistry and in situ hybridization results}

Positive expression of $\mathrm{Hpa}$ protein was determined by yellow, brown and tan particles in the cytoplasm (Figures 2A and B). Hpa mRNA was colored by NBT/BCIP, as shown in blue and purple granules. Positive signals were located in the cytoplasm (Figures $2 \mathrm{C}$ and D). Five high-perspectives under binocular microscope were selected in each slide, and 100 cells were counted randomly per field. Expression of Hpa protein and mRNA were scored based on integrated staining intensity and by the proportion of positive cells [48]. The percentage of positively stained cells was scored as $1(<5 \%$, negative), 2 (5-25\%, sporadic), 3 (25-50\%, focal) or 4 ( $>50 \%$, diffuse). Intensity of the hybridization signal was divided into 4 grades: no staining (1 score), weak (2 score), moderate (3 score) and strong (4 score). According to the product of the scores of positive cells and the scores of staining intensity, the expression level was defined as follows: $1+(<4$ scores $),++(4-8$ scores $),+++(9-12$ scores $),++++(13-16$ scores $)$.

\section{TaqMan real-time qRT-PCR}

For TaqMan real-time qRT-PCRs, Hpa and b2microglobulin were purchased from Ambion (Carlsbad, CA, USA; ID: Hs00935033_m1, and 4333766 F, respectively). PCRs were done with the ABI 7500 Fast Real Time PCR System (Applied Biosystems, Foster City, CA, USA). Amplification conditions were $2 \mathrm{~min}$ at $50^{\circ} \mathrm{C}$, $10 \mathrm{~min}$ at $95^{\circ} \mathrm{C}$ and then 40 cycles each consisting of $15 \mathrm{~s}$ at $95^{\circ} \mathrm{C}$ and $1 \mathrm{~min}$ at $60^{\circ} \mathrm{C}$. Hpa relative expression was assessed using the comparative $\mathrm{C}_{\mathrm{T}}$ method and presented as $2^{-\Delta c t}$ value. The fold changes of Hpa expression were calculated according to reference [49].

\section{Statistical methods}

SPSS10.0 software package (SPSS Inc., Chicago, IL, USA) was used for statistical analysis and calculating the $\mathrm{IC}_{50}$ of suramin. The values represent the mean \pm the SD of the values obtained. In some experiments, the GI\% was calculated, which represents the percentage increase or decrease in relation to the untreated control group. One way ANOVA was used to make comparisons between the groups. For the count data, the Chi-square test was used to calculate the significance of differences between the groups, with $p<0.05$ being taken as significant.

\section{Competing interests}

The authors declare that they have no competing interests.

\section{Authors' contributions}

$\mathrm{HPL}, \mathrm{JQC}$ designed and performed the research, analyzed the data, and drafted the manuscript; HLL, HJQ, BY, MZZ, MHC, analyzed the data. All of the authors read and approved the final manuscript. This project was supported by Health Bureau of Shanghai and the Youth Medical Worker Training Program of Health Bureau of Shanghai Pudong in china ,NO. 201440468 and PWRq2012-31.

\section{Authors' information}

Li HP: Master of medicine, Attending Surgeon in obstetrics and Gynecology,were selected in Youth Youth Medical Worker Training Program Program of Health Bureau of Shanghai Pudong in China, and Independently accomplished two scientific research projects supported by Health Bureau of Shanghai Pudong in China.

Cui JQ: Professor, MD, PhD and master tutor, member of Chinese Medical Association, vice-chairman of the professional group of gynecologic oncology in the Henan Branch.

\section{Author details}

${ }^{1}$ Department of Gynaecology and Obstetrics, Punan Hospital of Pudong District, South Pudong Road, Shanghai, China. ${ }^{2}$ Department of medicine laboratory, The Food and Drug Administration of pingdingshan, Labor Road, Pingdingshan, China. ${ }^{3}$ Department of Gynaecology and Obstetrics, The Second Affiliated Hospital of Zhengzhou University, Longitude eighth Road, Zhengzhou, China.

Received: 28 July 2014 Accepted: 12 April 2015

Published online: 13 May 2015

\section{References}

1. Siegel R, Naishadham D, Jemal A. Cancer statistics. 2012. CA Cancer J Clin. 2012;62:10-29.

2. Kaye SB, Lubinski J, Matulonis U, Ang JE, Gourley C, Karlan BY, et al. A Phase II, open-label, randomized, multicenter study comparing the efficacy and safety of olaparib, a poly (ADP-ribose) polymerase inhibitor, and pegylated liposomal doxorubicin in patients with BRCA1 or BRCA2 mutations and recurrent ovarian cancer. J Clin Oncol. 2012;30:372-9.

3. Burger RA, Brady MF, Bookman MA, Fleming GF, Monk BJ, Huang $\mathrm{H}$, et al. Incorporation of bevacizumab in the primary treatment of ovarian cancer. $\mathrm{N}$ Engl J Med. 2011;365:2473-83.

4. Perren TJ, Swart AM, Pfisterer J, Ledermann JA, Pujade-Lauraine E, Kristensen $\mathrm{G}$, et al. A phase 3 trial of bevacizumab in ovarian cancer. N Engl J Med. 2011;365:2484-96.

5. Aghajanian C, Blank SV, Goff BA, Judson PL, Teneriello MG, Husain A, et al. OCEANS: a randomized, double-blind, placebo-controlled phase III trial of chemotherapy with or without bevacizumab in patients with platinumsensitive recurrent epithelial ovarian, primary peritoneal, or fallopian tube cancer. J Clin Oncol. 2012;30:2039-45. 
6. Suh DH, Kim JW, Kim K, Kim HJ, Lee KH. Major clinical research advances in gynecologic cancer in 2012. J Gynecol Oncol. 2013;24:66-82.

7. Eskander RN, Tewari KS. Beyond angiogenesis blockade: targeted therapy for advanced cervical cancer. J Gynecol Oncol. 2014;25:249-59.

8. Barash U, Cohen-Kaplan V, Dowek I, Sanderson RD, Ilan N, Vlodavsky I. Proteoglycans in health and disease: new concepts for heparanase function in tumor progression and metastasis. FEBS J. 2010;277:3890-903.

9. Roy M, Marchetti D. Cell surface heparan sulfate released by heparanase promotes melanoma cell migration and angiogenesis. J Cell Biochem. 2009;106:200-9.

10. Purushothaman A, Uyama T, Kobayashi F, Yamada S, Sugahara K, Rapraeger AC, et al. Heparanase-enhanced shedding of syndecan-1 by myeloma cells promotes endothelial invasion and angiogenesis. Blood. 2010;115:2449-57.

11. Cohen I, Pappo O, Elkin M, San T, Bar-Shavit R, Hazan R, et al. Heparanase promotes growth, angiogenesis and survival of primary breast tumors. Int $J$ Cancer. 2006;118:1609-17.

12. Ginath S, Menczer J, Friedmann $Y$, Aingorn H, Aviv A, Tajima K, et al. Expression of heparanase, Mdm2, and erbB2 in ovarian cancer. Int J Oncol. 2001:18:1133-44.

13. Kodama J, Shinyo Y, Hashen G, Hongo A, Yoshinouchi M, Hiramatsu Y. Heparanase messenger RNA expression in epithelial ovarian tumor. Int J Mol Med. 2003;12:961-4.

14. Zeng C, Ke ZF, Luo WR, Yao YH, Hu XR, Jie W, et al. Heparanase overexpression participates in tumor growth of cervical cancer in vitro and in vivo. Med Oncol. 2013;30:403.

15. Davidson B, Shafat I, Risberg B, Ilan N, Trope' CG, Vlodavsky I, et al. Heparanase expression correlates with poor survival in metastatic ovarian carcinoma. Gynecol Oncol. 2007;104:311-9.

16. Shinyo Y, Kodama J, Hongo A, Yoshinouchi M, Hiramatsu Y. Heparanase expression is an independent prognostic factor in patients with invasive cervical cancer. Ann Oncol. 2003;14:1505-10.

17. Zhang W, Yang HC, Wang Q, Yang ZJ, Chen H, Wang SM, et al. Clinical value of combined detection of serum matrix metalloproteinase- 9 , heparanase, and cathepsin for determining ovarian cancer invasion and metastasis. Anticancer Res. 2011;31:3423-8.

18. Basappa J, Murugan S, Kavitha CV, Purushothaman A, Nevin KG, Sugahara K, et al. A small oxazine compound as an anti-tumor agent: a novel pyranoside mimetic that binds to VEGF, HB-EGF, and TNF-alpha. Cancer Lett. 2010;297:231-43

19. Kudchadkar R, Gonzalez R, Lewis KD. PI-88: a novel inhibitor of angiogenesis. Expert Opin Investig Drugs. 2008;17:1769-76.

20. Khasraw M, Pavlakis N, McCowatt S, Underhill C, Begbie S, de Souza P, et al. Multicentre phase I/II study of PI-88, a heparanase inhibitor in combination with docetaxel in patients with metastatic castrate-resistant prostate cancer. Ann Oncol. 2010;21:1302-7.

21. Taylor CW, Lui R, Fanta P, Salmon SE. Effects of suramin on in vitro growth of fresh human tumors. J Natl Cancer Inst. 1992;84:489-94.

22. Lam ET, Au JL, Otterson GA, Guillaume Wientjes M, Chen L, Shen T, et al. Phase I trial of non-cytotoxic suramin as a modulator of docetaxel and gemcitabine therapy in previously treated patients with non-small cell lung cancer. Cancer Chemother Pharmacol. 2010;66:1019-29.

23. Hutson PR, Tutsch KD, Rago R, Arzoomanian R, Alberti D, Pomplun M, et al. Renal clearance, tissue distribution, and CA-125 responses in a phase I trial of suramin. Clin Cancer Res. 1998;4:1429-36.

24. Larsen AK. Suramin: an anticancer drug with unique biological effects. Cancer Chemother Pharmacol. 1993;32:96-8.

25. Nakajima M, De Chavigny A, Johnson CE, Hamada J, Stein CA, Nicolson GL. Suramin. A potent inhibitor of melanoma heparanase and invasion. J Biol Chem. 1991;266:9661-6.

26. Firsching A, Nickel P, Mora P, Allolio B. Antiproliferative and angiostatic activity of suramin analogues. Cancer Res. 1995;55:4957-61.

27. Parish CR, Freeman C, Brown KJ, Francis DJ, Cowden WB. Identification of sulfated oligosaccharide-based inhibitors of tumor growthand metastasis using novel in vitro assays for angiogenesis and heparanase activity. Cancer Res. 1999;59:3433-41.

28. Marchetti D, Reiland J, Erwin B, Roy M. Inhibition of heparanase activity and heparanase-induced angiogenesis by suramin analogues. Int J Cancer. 2003; 104:167-74

29. Sadashiva MP, Basappa S, Nanjundaswamy S, Li F, Manu KA, Sengottuvelan $M$, et al. Anti-cancer activity of novel dibenzo[b, f]azepine tethered isoxazoline derivatives. BMC Chem Biol. 2012;12:5.
30. Kaur M, Reed E, Sartor O, Dahut W, Figg WD. Suramin's development: what did we learn? Invest New Drugs. 2002;20:209-19.

31. Reed E, Cooper MR, LaRocca RV, Bostick-Bruton F, Myers CE. Suramin in advanced platinum-resistant ovarian cancer. Eur J Cancer. 1992;28A:864-6.

32. Kikuchi Y, Hirata J, Hisano A, Tode T, Kita T, Nagata I. Complete inhibition of human ovarian cancer xenografts in nude mice by suramin and cis-diamminedichloroplatinum(II). Gynecol Oncol. 1995;58:11-5.

33. La Rocca RV, Meer J, Gilliatt RW, Stein CA, Cassidy J, Myers CE, et al. Suramin-induced polyneuropathy. Neurology. 1990;40:954-60.

34. Kobayashi K, Weiss RE, Vogelzang NJ, Vokes EE, Janisch L, Ratain MJ. Mineralocorticoid insufficiency due to suramin therapy. Cancer. 1996;78:2411-20.

35. Figg WD, Cooper MR, Thibault A, Headlee D, Humphrey J, Bergan RC, et al. Acute renal toxicity associated with suramin in the treatment of prostate cancer. Cancer. 1994;74:1612-4.

36. Song S, Wientjes MG, Gan Y, Au JL. Fibroblast growth factors: an epigenetic mechanism of broad spectrum resistance to anticancer drugs. Proc Natl Acad Sci U S A. 2000;97:8658-63.

37. Blum JL, Dees EC, Chacko A, Doane L, Ethirajan S, Hopkins J, et al. Phase II trial of capecitabine and weekly paclitaxel as first-line therapy for metastatic breast cancer. J Clin Oncol. 2006;24(27):4384-90.

38. Lustberg MB, Pant S, Ruppert AS, Shen T, Wei Y, Chen L, et al. Phase I/II trial of non-cytotoxic suramin in combination with weekly paclitaxel in metastatic breast cancer treated with prior taxanes. Cancer Chemother Pharmacol. 2012;70:49-56.

39. Horiuchi KY, Eason MM, Ferry JJ, Planck JL, Walsh CP, Smith RF, et al. Assay development for histone methyltransferases. Assay Drug Dev Technol. 2013;11:227-36

40. Botta G, De Santis LP, Saladino R. Current advances in the synthesis and antitumoral activity of SIRT1-2 inhibitors by modulation of p53 and pro-apoptotic proteins. Curr Med Chem. 2012;19:5871-84.

41. Iglesias RM, Spray DC. Pannexin1-mediated ATP release provides signa transmission between Neuro2A cells. Neurochem Res. 2012;37:1355-63.

42. Singh PK, Chan PF, Hibbs MJ, Vazquez MJ, Segura DC, Thomas DA, et al. High-yield production and characterization of biologically active GST-tagged human topoisomerase lla protein in insect cells for the development of a high-throughput assay. Protein Expr Purif. 2011;76:165-72.

43. Alonso I, Torné A, Puig-Tintoré LM, Esteve R, Quinto L, Garcia S, et al. High-risk cervical epithelial neoplasia grade 1 treated by loop electrosurgical excision: follow-up and value of HPV testing. Am J Obstet Gynecol. 2007;197:359. e1-6.

44. Walboomers JM, Jacobs MV, Manos MM, Bosch FX, Kummer JA, Shah KV, et al. Human papillomavirus is a necessary cause of invasive cervical cancer worldwide. J Pathol. 1999;189:12-9.

45. Leemans $\mathrm{CR}$, Braakhuis BJ, Brakenhoff $\mathrm{RH}$. The molecular biology of head and neck cancer. Nat Rev Cancer. 2011;11:9-22.

46. Hirshoren N, Bulvik R, Neuman T, Rubinstein AM, Meirovitz A, Elkin M. Induction of heparanase by HPV E6 oncogene in head and neck squamous cell carcinoma. J Cell Mol Med. 2014;18:181-6.

47. Wang $\mathrm{H}, \mathrm{Mo}$ P, Ren S, Yan C. Activating transcription factor 3 activates p53 by preventing E6-associated protein from binding to E6. J Biol Chem. 2010:285:13201-10.

48. Kang KF, Wang XW, Chen XW, Kang ZJ, Zhang X, Wilbur RR, et al. Beclin 1 and nuclear factor-KBp65 are upregulated in hepatocellular carcinoma. Oncol Lett. 2013;5:1813-8.

49. Schmittgen TD, Livak KJ. Analyzing real-time PCR data by the comparative C(T) method. Nat Protoc. 2008;3:1101-8. 